oak, which has persisted less than anticipated. On the other hand, several important features were anticipated. The persistence of maple, birch and minor; the transitions from oak to maplo and birch; the transitions from birch to maple; and the transitions from other and minor to maple and birch could have been rather well predicted in 1937 by manipulating the matrix of probabilities for the first decade, as is done in the middle of Table 1.

Although the plots were not numerous enough to divide into twenty-five classes, they were divided into older and younger forests. They were also divided into moister and drier groups. The probabilities were reassuringly similar in different groups.

Table 2. PERCENTAGes OF FOREST PLOTS IN FTVE CLASSES AT STEADY STATE ANTICIPATED FROM TRANSITIONS OBSERVED IN TWO DECADES

$\begin{array}{cccccc}\text { Observations } & \text { Maple } & \text { Oak } & \text { Birch } & \text { Other } & \text { Minor } \\ 1927-1937 & 39 & 17 & 22 & 5 & 17 \\ 1957-1967 & 45 & 1 & 32 & 6 & 17\end{array}$

The final comparison is between the stcady states anticipated from the transitions of the first and last decades. If the changes in tho forest were an ideal stationary Markov chain, the two steady states would be the same. Whether the transitions of the thickets of 1927-37 or forests of 1957-1967 were extrapolated, the prediction was about the same: many plots of maple or birch, some minor and few oak or other ('Table 2). The last decade of drought and defoliation did not change the direction of trends evident in the first decade. Thus the foresight of our predecessors who established the plots has permitted a demenstration that some transition probabilities for the forest can be treated as if they came from a stationary Markov chain, providing both an orderly way of comparing forest changes during periods of different longth and of extrapolating into the future.

PAUL E. WAGgoner

George R. Stephens

Connecticut Agricultural

Experiment Station,

New Haven,

Connecticut 06504.

Received November 3, 1969.

- Feller, W., An Introduction to Probability Theory and its Application, 1 (Wiley, New York, 1957)

${ }^{2}$ Hicock, H. W., Morgan, M. F., Lutz, H. J., Bull, H., and Lunt, H. A. Conn Agric. Exp. Sta. Bull., 330 (1931).

${ }^{3}$ Olson, A. R., Conn. Agric. Sta. Bull., 669 (1965).

"Stephens, G. R., and Waggoner, P. E., Conn. Agric. Sta. Bull., 707 (in the press).

\section{Possible Side Effects of Fungicides on Banana and Coffee Diseases}

ExPERIENCE suggests that excessive application of fungicidal sprays to crops has not had as many undesirable biological side effects as the excessive application of insecticides. Nor has there been much evidence, at least at the level of field application, of acquired resistance to fungicides ${ }^{1}$.

There are various ways in which fungicide sprays may have an effect other than that intended, and in this respect recent publications on the non-parasitic microflora of leaves are interesting. Hislop and $\mathrm{Cox}^{2}$, for example, discussed the implication of fungicide usage in relation to the balance of saprophytic and parasitic microorganisms of the phylloplane. And Furtado ${ }^{3}$ emphasized that copper sprays bring about an increase in the population of virulent Colletotrichum coffeanum Noack in coffee bark. $\mathrm{He}$ quoted how coffee berry disease increased in Kenya as a rosult of copper spraying. Wallis and $\mathbf{I}^{4}$ produced experimental evidence for this in 1967.

This apparent favouring of a virulent pathogen at the expense of a related saprophytic or less virulent form is a most interesting fungicidal side effect. The recent replacement of Mycosphaerella musicola Leach, the cause of Sigatoka disease of bananas, by Mycosphaerella sp., the cause of the much more serious black leaf streak disease, in Fiji and other Pacific territories could be viewed in this light. Details of this disease and its geographic distribution and spread have been described several times ${ }^{5-8}$. The black leaf streak fungus produces conidiophores sparsely and ascospores abundantly, in contrast to $M$. musicola which produces dense fascicles of conidiophores and relatively few ascospores. When he first observed this disease Rhodes ${ }^{9}$ noted it on plantings where Sigatoka disease had previousiy been controlled effectively by oil spraying, which was not controlling the new disease satisfactorily. Stover and Dickson ${ }^{10}$ noted that one of the effects of oil on $M$. musicola was to reduce the number of sporodochia and thus the number of conidiophores. It is conceivable that oil favours a form which already has the habit of sparse conidiophore production and relies chiefly on ascospore infection.

It can be argued that black leaf streak disease has so far not been reported in the principal banana producing countries where oil spraying is common. But coffee berry disease is not present in the principal coffee producing countries although Colletotrichum coffeanum is ubiquitous. Only in parts of Africa has there been replacement by a virulent strain. The mechanism by which these two virulent fungi have become prevalent is not known, and no similarity is now suggested. But the situation provides a warning that we should perhaps examine the effects of fungicide as carefully as those of other chemicals used for plant protection.

Department of Agriculture,

I. D. FirmaN Suva, Fiji.

Received January 6, 1970.

${ }^{1}$ Sisler, H. D., and Cox, C. E., Plant Pathology, 2 (Academic Press, 1960).

${ }^{2}$ Hislop, F. C., and Cox, T. W.. Trans. Brit. Mycol. Soc., 52 (2), 223 (1969).

${ }^{3}$ Furtado, I., Trans. Brit. Mycol. Soc., 53 (2), 325 (1969).

'Wallis, J. A. N., and Firman, I. D., Ann. Appl. Biol., 59, 111 (1967).

'Leach, R., Coun. Pap. Fiji, No. 38 (1964).

"Graham, K. M., Dept. Agric. Fiji, Bull., 49 (1969).

${ }^{7}$ Meredith, D. S., and Lawrence, J. S., Trans. Brit. Mycol. Soc., 52 (3), 459 (1969)

${ }^{8}$ Meredith, D. S., and Firman, I. D., Trop. Agric. Trinidad, 47 (in the press).

${ }^{9}$ Rhodes, P. T., Commonwealth Phytopathol. News, 10, 38 (1964).

${ }^{10}$ Stover, R. H., and Dickson, J. D., Canad. J. Bot., 46, 1495 (1968).

\section{Hemiparasitic Flowering Plants: Phenotypic Canalization by Hosts}

THE idea of combining the desired qualities of two distinct genotypes is old and universally appreciated. The genetic information can be brought together in two ways: within the same zygote through hybridization; or, for example, in higher plants, by grafting the stem of a superior fruit onto a particularly hardy root system. It is increasingly clear that the phenomenon of grafting (like hybridization) is a common natural process in which the root systems (and stems) of genetically distinct individuals become functionally interconnected.

Such interconnexions are formed naturally in at least three ways: by mycorrhizal fungi ${ }^{1,2}$, by natural root grafting among forest trees ${ }^{3}$ and through the haustorial connexions of holoparasitic and hemiparasitic vascular plants (sce, for example, ref. 4). Although the mechanisms of coupling and transfer differ markedly in these bridgeforming plants, they have in common the eapacity to share the biochemical products of other genetically distinct individuals.

The hemiparasitic flowering plants that live in annual grasslands are of special interest because cach year they come into random contact with a wide range of potential 